This document was prepared in conjunction with work accomplished under Contract No. DE-AC09-96SR18500 with the U.S. Department of Energy.

This work was prepared under an agreement with and funded by the U.S. Government. Neither the U. S. Government or its employees, nor any of its contractors, subcontractors or their employees, makes any express or implied: 1 . warranty or assumes any legal liability for the accuracy, completeness, or for the use or results of such use of any information, product, or process disclosed; or 2 . representation that such use or results of such use would not infringe privately owned rights; or 3 . endorsement or recommendation of any specifically identified commercial product, process, or service. Any views and opinions of authors expressed in this work do not necessarily state or reflect those of the United States Government, or its contractors, or subcontractors. 
Proceeding of PVP2007-26330

2007 ASME Pressure Vessels and Piping Division Conference

July 22-26, 2007, San Antonio, Texas

PVP2007-26330

\title{
EFFECT OF IMPACT LIMITER MATERIAL DEGRADATION ON STRUCTURAL INTEGRITY OF 9975 PACKAGE SUBJECTED TO TWO FORKLIFT TRUCK IMPACT
}

\author{
Tsu-te Wu \\ Savannah River National Laboratory \\ Aiken, South, Carolina 29808 \\ (803) 725-8201, tsu-te.wu@srs.gov
}

\begin{abstract}
ABASTRACT
This paper evaluates the effect of the impact limiter material degradation on the structural integrity of the 9975 package containment vessel during a postulated accident event of forklift truck collision.

The analytical results show that the primary and secondary containment vessels remain structurally intact for Celotex material degraded to $20 \%$ of the baseline value.
\end{abstract}

\subsection{INTRODUCTION}

The Savannah River Site (SRS) will use 9975 Packages as radioactive materials storage containers. During package handling, a forklift impact accident is postulated to occur. The performance of the package in protecting the contained primary and secondary containment vessels is largely a function of the strength of Celotex brand cane fiberboard overpack material used for absorbing impact energy.

Previous analyses [1] of the 9975 package for the forklift truck accidental impact were based on a single specific non-degraded mechanical strength level (e.g. stress-strain curve). However, aging of cane fiberboards in various environments will result in accelerated material degradation. In the development of baseline mechanical properties for surveillance, it was concluded that the use of a single stress-strain curve for Celotex strength may be non-conservative for some extreme conditions. As a result, series analyses were performed to evaluate the effect of cane fiberboard material property variation on the structural integrity of the 9975 package primary and secondary Containment Vessels.

\subsection{POSTULATED ACCIDENT EVENT}

A postulated accident is a forklift truck carrying four packages in a 2x2 array encountering another forklift truck from the opposite direction. The oncoming truck first accidentally knocks off a front row package and its tine then directly punctures a back row package. The back row package is then subjected to compressive forces from two forklifts traveling in opposite directions.

\subsection{ANALYSIS}

\section{Material Properties}

Previous structural analyses [1] of the 9975 package subjected to two forklift truck impacting loads were based on baseline mechanical properties for the cane fiberboard. However, environmental aging of cane fiberboard will result in degradation of the baseline mechanical properties. The analysis presented in this paper represents the can fiberboard strength parametrically as the baseline stress-strain curve multiplied by a strength reduction factor. Strength reduction factors of $50 \%, 40 \%, 30 \%, 25 \%$, and $20 \%$ are applied to the baseline compression test data reported in [6], as shown in Figure 1.

The mechanical properties of the materials used in the 9975 package except Cane fiberboard are documented in $[1,4,5]$.

\section{Finite Element Model}

The shipping package impact accident is evaluated by the finite element method using the ABASUS/Explicit computer code [2]. The MSC/PATRAN computer program [3] is used to develop the finite-element models. The basic geometry of a 9975 package is shown in Figure 2. The principal components shown in the figure are described in Table 1.

Since the arrangement of the 9975 package and the impacting objects is symmetric about a vertical plane, only 
one half of the package is modeled (Figures 3 and 4). For better visualization, the full forklift tine, lift frame and pallet are shown in the finite-element model.

The finite element models of the Drum, Steel Tube Liner, SCV, and PCV are comprised of 3D shell elements (Type S4R). The Foam and Lead Shield are modeled using 3D brick elements (C3D8R). The forklift tine, pallet, and the wall, against which the package would be pinned during the collision, are modeled with 3D rigid elements (R3D4). The weights and motion of the two forklift trucks are modeled by using concentrated masses. The SCV and PCV closure threads that hold the cone seal nuts are each represented by an equivalent ring consisting of 3D shell elements with the ring cross sectional area equal to the total threat area. The shear area of each ring is equivalent to each thread shear area.

Figure 3 illustrates the case of the Primary Containment Vessel (PCV) closure impact. Figure 4 depicts the case of the PCV and Secondary Containment Vessel (SCV) head impact. These impacts targets were identified in sensitivity analyses using a simplified PCV and SCV model.

\section{Boundary Conditions}

Symmetry boundary conditions are applied to the model cutplane. The reference nodes of the forklift truck carrying the impacted package and the impacting forklift tine are fixed about all degrees-of-freedom, except for the single translation direction which has the imposed initial velocity defined below.

\section{Weight of Impacting Forklift Truck}

The weights of the forklift trucks are modeled by attaching concentrated masses at the respective reference nodes. Since only a symmetric half of the package is modeled, the attached mass is only half of the 20,000-pound forklift weight. The forklift lump mass is therefore equal to 25.88

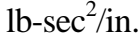

\section{Weight of Forklift Truck Carrying Package}

The weight of the pallet is equal to 475.745 pounds and the weight of package is 404 pounds. This forklift carries a pallet and three 9975 packages (one of the four packages originally carried is assumed to be knocked out of the pallet by the other forklift truck). Thus, the total weight of this forklift truck is:

$$
\mathrm{W}=20000+474.745+3 x 404=21,686.745 \text { lbs } .
$$

One half of the mass of the concentrated mass model for this forklift truck is then equal to $28.06 \mathrm{lbs}-\mathrm{sec}^{2} / \mathrm{in}$.

\section{Forklift Speed}

The maximum speed of the forklift truck is $7 \mathrm{mph}(123.2$ $\mathrm{in} / \mathrm{sec}$ ), imposed as an initial condition to the forklift reference nodes, in opposite directions.

\section{Contact Conditions}

The analyses involve monitoring a large number of contact conditions. The combination of the "General Contact" method and the "Contact Pair" method is used to simulate the interface variations among the neighboring components of the package.

\subsection{DEVELOPMENT OF FAILURE CRITERION}

The postulated accident condition of the 9975 package impacted by the forklift tine during handling is not one of the Hypothetical Accident Conditions (HAC) for the transport of radioactive materials defined in Regulatory Guide 7.8 [7]. Therefore, it is not required to satisfy the criteria specified in the ASME Code, Section III, for Level D service loads [8].

Based on information given in [4], the engineering strain capability corresponding to the ultimate strength of stainless steel $304 \mathrm{~L}$ is conservatively set to be 0.4 . Beyond the ultimate stress, the test specimen necks down rapidly and a complicated tri-axial state of stress exits. Consequently, the engineering strain limit of 0.4 is selected as the basis for defining an applicable failure strain criterion. A true strain of 0.336 corresponds to an engineering strain of 0.4. The corresponding elastic strain is very small and can be calculated as follows.

$$
\varepsilon_{e}=\frac{\sigma_{y}}{E}=\frac{37840}{28300000}=0.00134
$$

where the value of the yield stress, $\sigma_{y}$, and Young's modulus, $E$, are obtained from [5]. The portion of the plastic strain is:

$$
\varepsilon_{p}=0.336-0.00134=0.33466
$$

Consequently, it is appropriate to choose the value of 0.33 as the allowable limit of the equivalent plastic strain. The failure criterion of the present analyses is therefore:

$$
\text { peeq } \leq 0.33
$$

The equivalent plastic strain, peeq, is defined in the ABAQUS Code as follows:

$$
\text { peeq }=\int_{0}^{t} \dot{\varepsilon}_{p} d t
$$


where $\dot{\varepsilon}_{p}$ is defined in terms of the principal plastic strain increments, $\dot{\varepsilon}_{1}^{p}, \dot{\varepsilon}_{2}^{p}$, and $\dot{\varepsilon}_{3}^{p}$ in the following form.

$$
\dot{\varepsilon}_{p}=\frac{\sqrt{2}}{3}\left[\left(\dot{\varepsilon}_{1}^{p}-\dot{\varepsilon}_{2}^{p}\right)^{2}-\left(\dot{\varepsilon}_{2}^{p}-\dot{\varepsilon}_{3}^{p}\right)^{2}-\left(\dot{\varepsilon}_{3}^{p}-\dot{\varepsilon}_{1}^{p}\right)^{2}\right]^{1 \frac{1}{2}}
$$

\subsection{DISCUSSION OF ANALYTICAL RESULTS}

The analyses for reduced Celotex material properties were performed sequentially in the order corresponding to $50 \%$, $40 \%, 30 \%, 25 \%$ and $20 \%$ of material strength (Figure 1). Only the solution results for the lowest strength Celotex material considered (20\%) are presented.

\subsection{Analysis for Puncture at PCV Closure}

\section{Displacement of Forklift Trucks}

Figure 5 displays the displacement time histories of the forklift truck whose tine punctures the 9975 package (Tine Displacement) and the forklift truck that carries the package (Pallet Displacement). The figure shows that the duration of the collision ends at the instant of 0.075 seconds and starts to rebound backwards due to the restored elastic energy. Since the friction between the truck and the floor is not modeled, the trucks will continue to move backwards.

\section{Deformed Shape of Model}

Figure 6 shows the deformed shape of the model.

\section{Damaged Shape of Package}

Figure 7 shows the damaged package with the Celotex removed for clarity.

\section{Equivalent Plastic Strains}

As shown in Figures 8 and 9, the maximum equivalent plastic strains in both PCV and SCV walls are less than the allowable value of 0.33 and thus they will not be ruptured.

\subsubsection{Analysis for Puncture at PCV and SCV Heads}

\section{Displacement of Forklift Trucks}

Figure 10 displays the displacement time histories of the forklift truck whose tine punctures the package (Tine Displacement) and the forklift truck that carries the package (Pallet Displacement). The figure shows that the duration of the collision ends at the instant of 0.075 seconds and starts to rebound backwards due to the restored elastic energy. Since the friction between the truck and the floor is not modeled, the trucks will continue to move backwards.

\section{Deformed Shape of Model}

Figure 11 shows the deformed shape of the model.

\section{Damaged Shape of Package}

Figure 12 shows the damaged package with the Celotex removed for clarity.

\section{Equivalent Plastic Strains}

As shown in Figures 13 and 14, the maximum equivalent plastic strains in both PCV and SCV are less than the allowable value of 0.33 and thus they will not be ruptured.

\subsection{Conclusions}

This paper evaluates the degradation effect of Celotex crane fiberboard materials due to aging on impact-limiting performance. The nonlinear dynamic analyses were performed for a 9975 package subjected to the impact loads resulting from the postulated accident conditions of twoforklift-truck collision. The levels of reduction in energy absorption capability of Celotex materials were represented by the baseline stress-strain curve multiplied by various reduction factors.

The analytical results show that both the primary and secondary containment vessels remain structurally intact for condition where the Celotex material degrades to $20 \%$ of the baseline stress-strain curve.

\subsection{REFERENCE}

1. Wu, T. T., "Structural Analysis of 9975 Package Subjected to Two Forklift Truck Impact," M-CLCK-00657, Rev.0.

2. ABAQUS/Explicit Analysis User Manual, Version 6.5, ABAQUS, Inc.

3. MSC/PATRAN, Version 2003 r2, MacNealSchwendler Corp.

4. Sindelar, R. L., "Tensile Properties of Type 304/304L Stainless Steel for Impact Deformation Analysis of Nuclear Containers," SRT-MTS-933113, Nov. 10, 1993.

5. Gong, C. and Miller, R. F., "Simulation and Analysis of the Plutonium Oxide/Metal Storage Containers Subject to Various Loading Conditions (U),” WSRC-TR-95-0070, May 1995.

6. Daugherty, W. L., "Baseline Mechanical Property Data for Package Celotex Material (U)," WSRCTR-2004-00523, December 2004. 
7. Regulatory Guide 7.8, U. S. Nuclear Regulatory Commission -- Load combinations for the Structural Analysis of Shipping Casks for Radioactive Material .

8. 2004 ASME Boiler and Pressure Vessel Code, Section III, Division 1, Appendix F -- Rules for Evaluation of Service Loadings with Level D Service Limits.

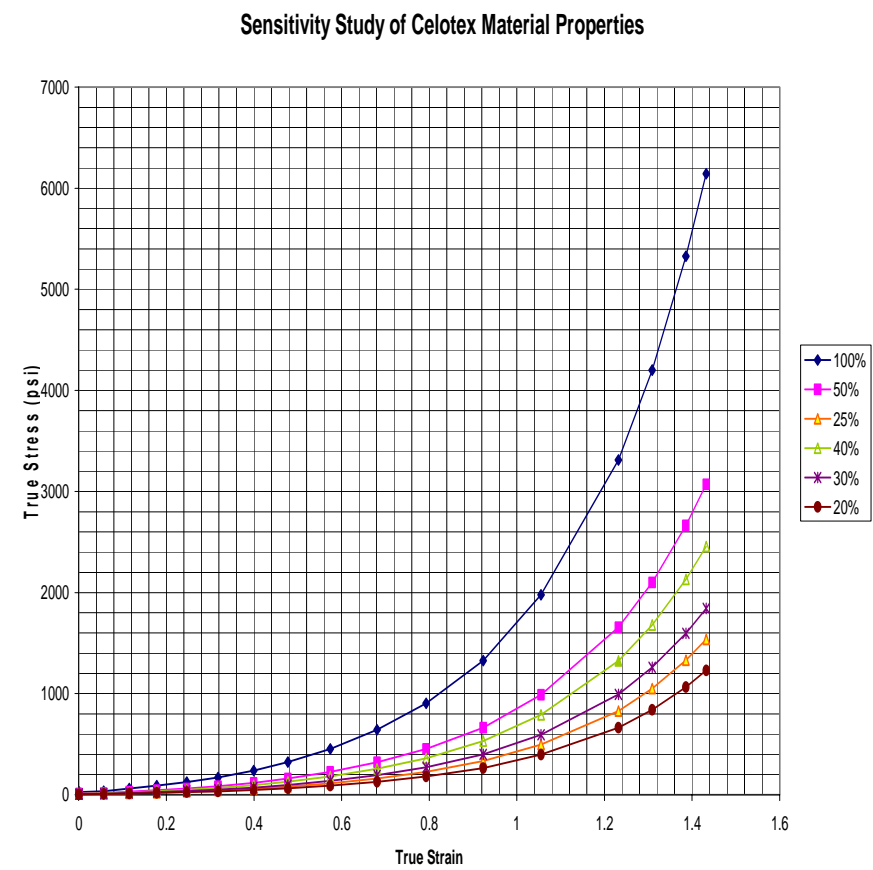

Figure 1. True Stress vs. True Strain Curves of Cane Fiberboard for Various Levels of Energy Absorption Capability

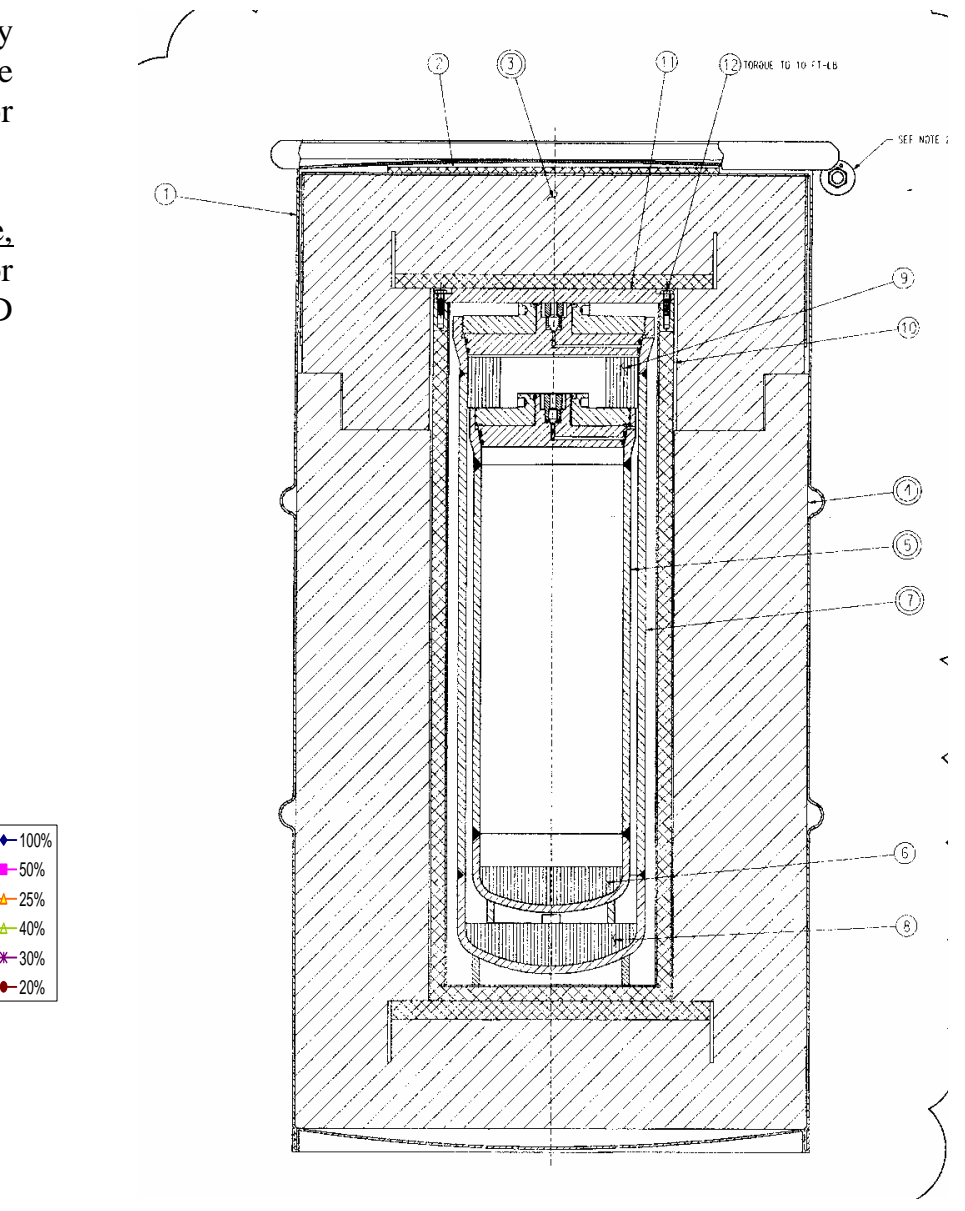

Figure 2. 9975 Package

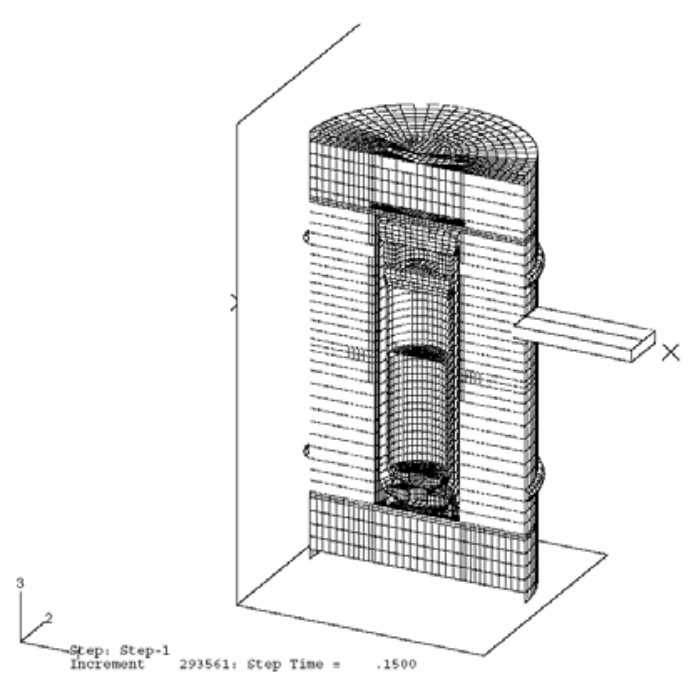

Figure 3. Finite-Element Model of PCV Closure Impact 


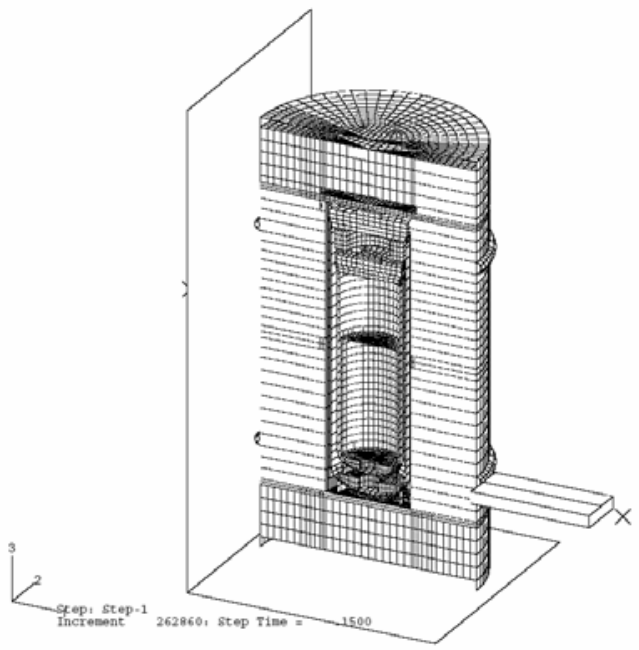

Figure 4. Finite-Element Model of PCV-SCV Head Impact

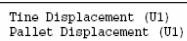

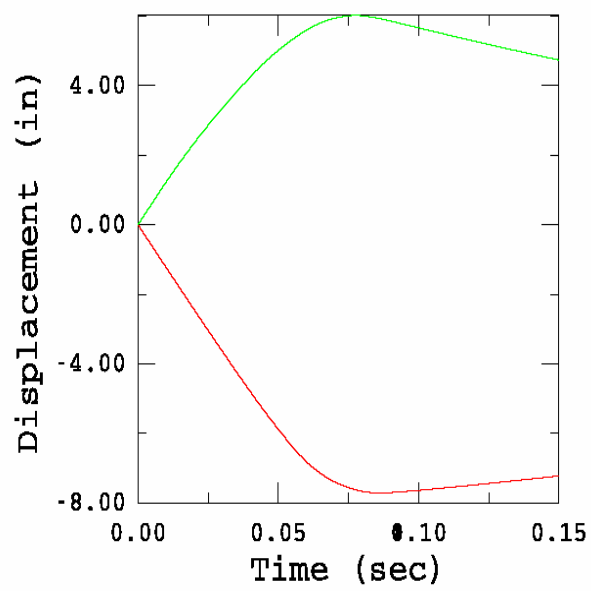

Figure 5. Displacement History of Forklift Trucks for PCV Closure Impact (20\% Celotex Strength)

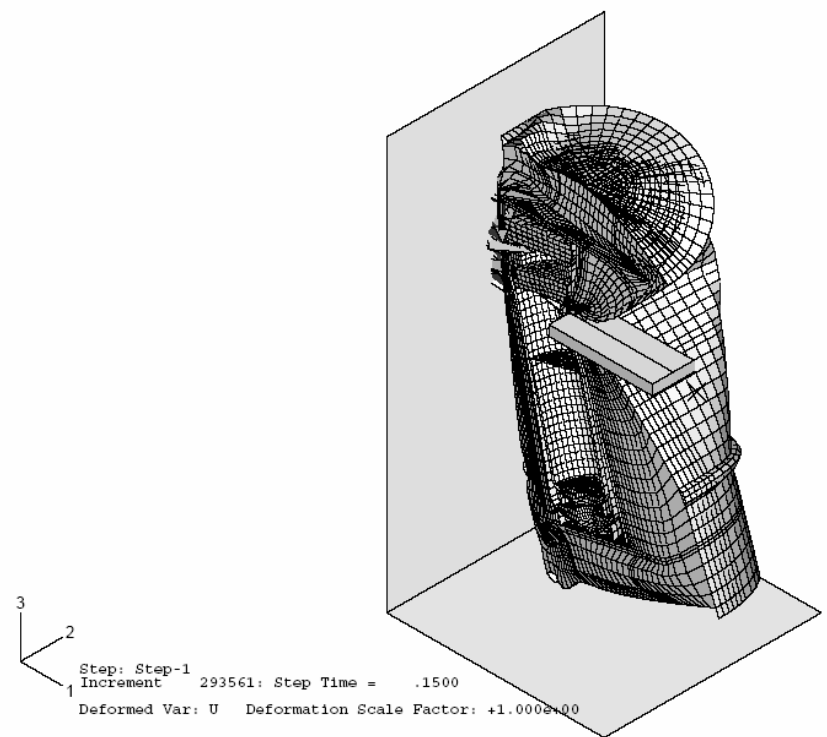

Figure 6. Displacement History of Forklift Trucks for PCV Closure Impact (20\% Celotex Strength)
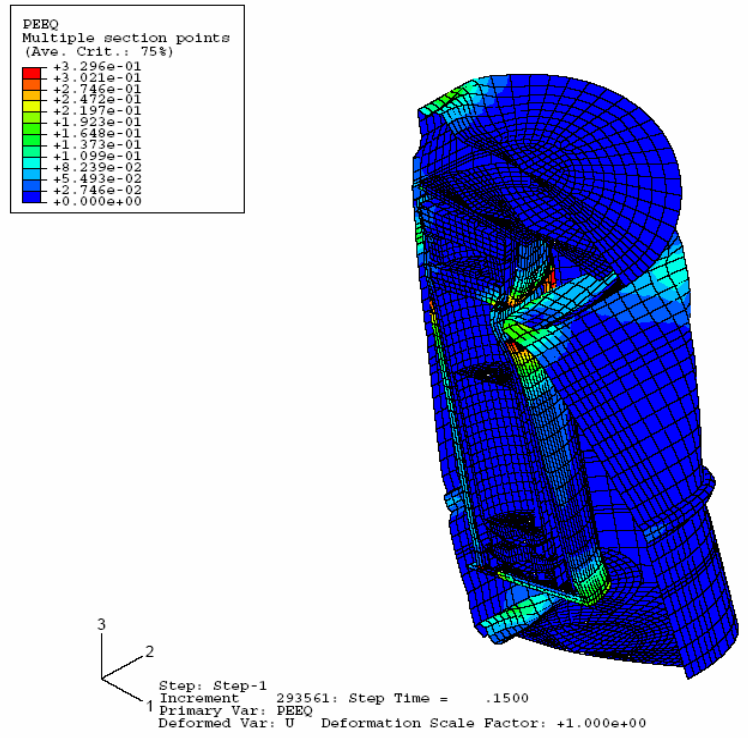

Figure 7. Damaged Shape for PVC Closure Impact (20\% Celotex Strength) 

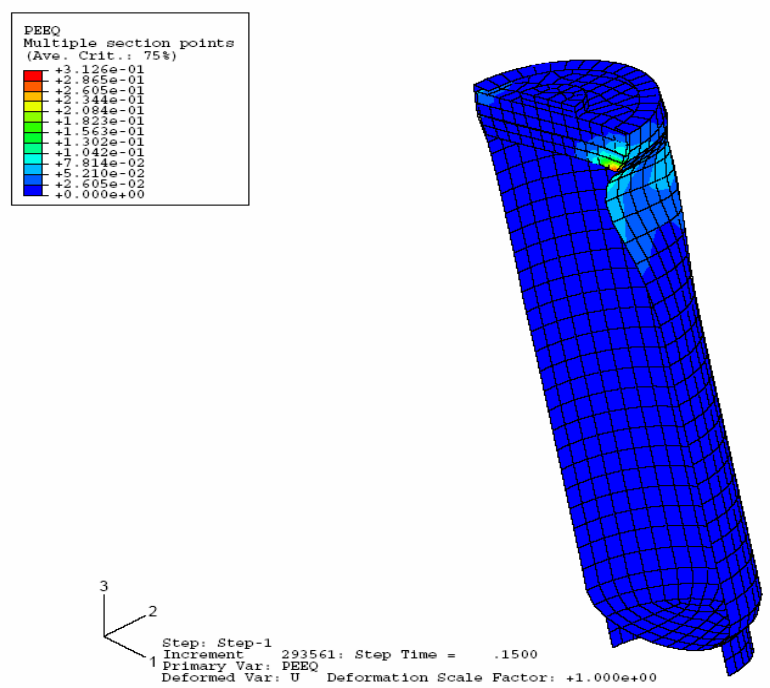

Figure 8. Plastic Strains in PCV for PCV Closure Impact (20\% Celotex Strength)
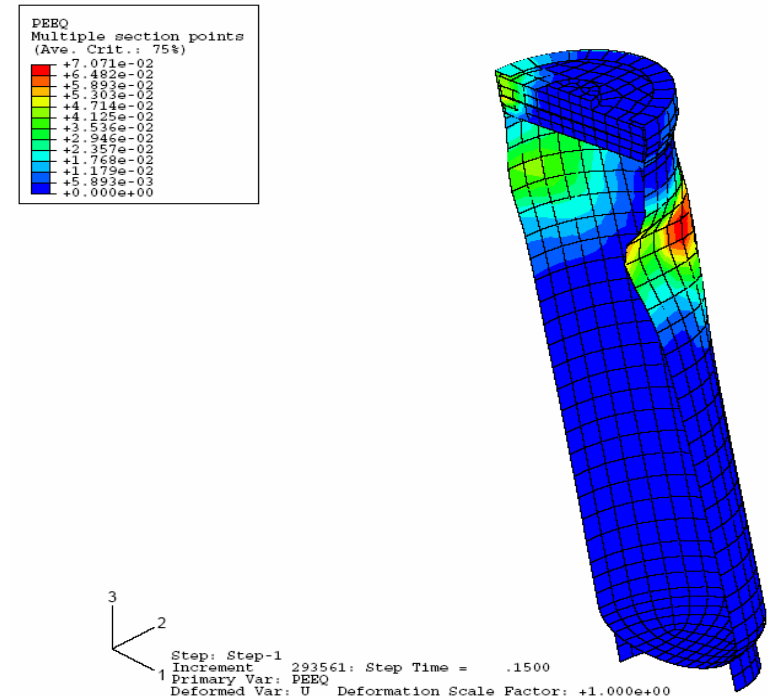

Figure 9. Plastic Strains in SCV for PCV Closure Impact (20\% Celotex Strength)

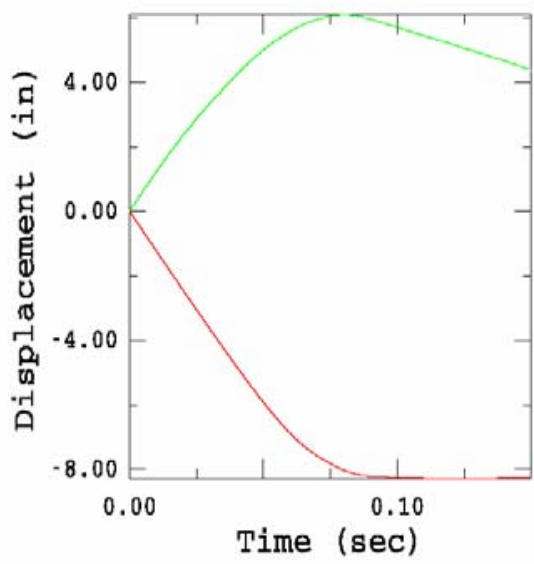

Figure 10. Displacement History of Forklift Trucks for PCV and SCV Head Impact (20\% Celotex Strength)

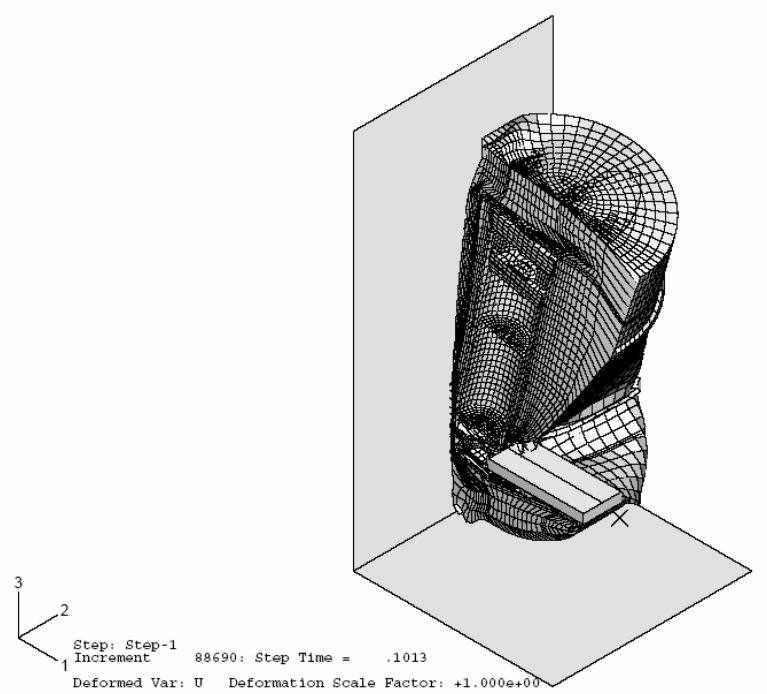

Figure 11. Displacement History of Forklift Trucks for PCV and SCV Head Impact (20\% Celotex Strength) 

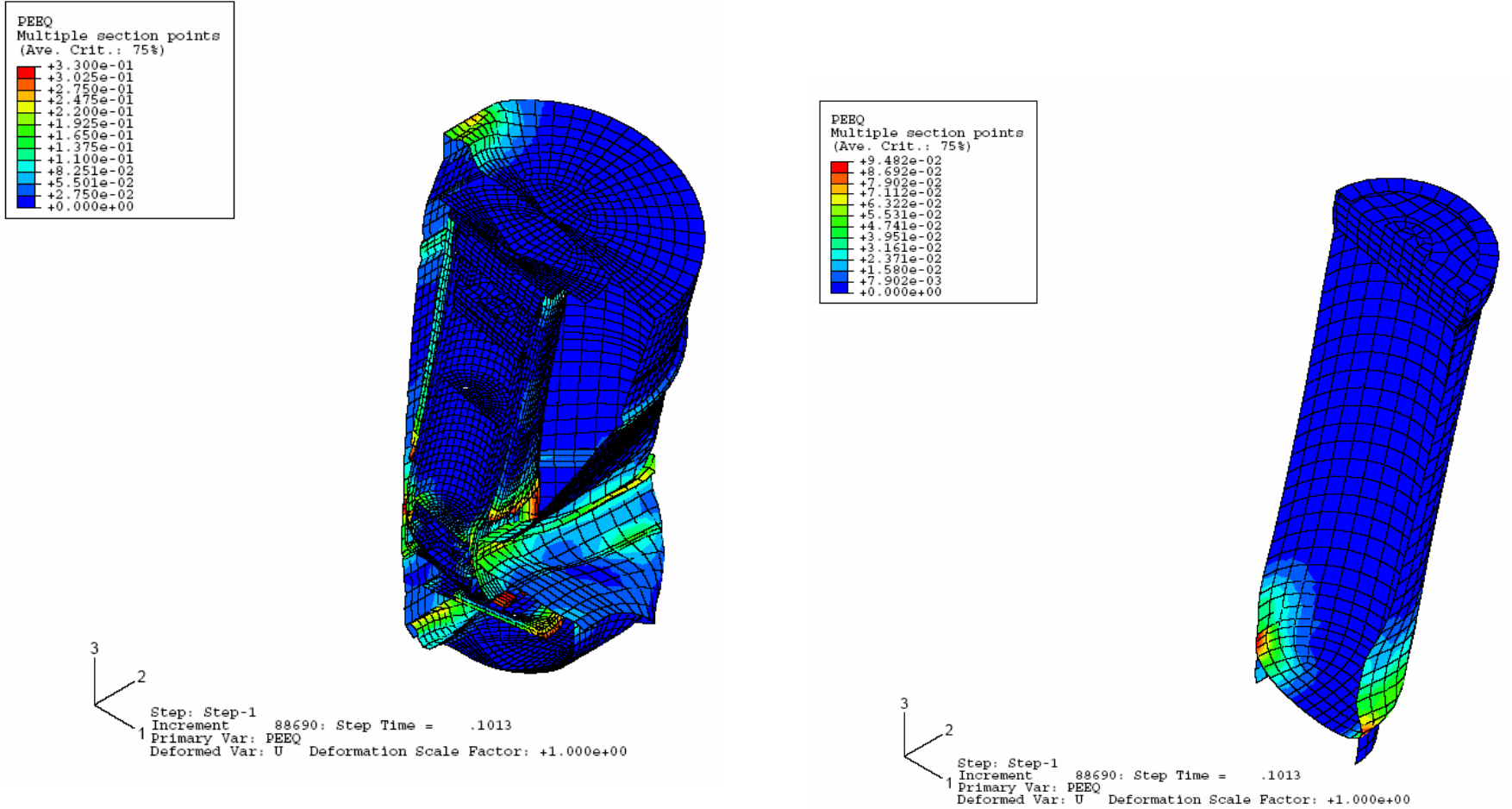

Figure 12. Damaged Shape for PCV and SCV Head Impact (20\% Celotex Strength)

Figure 14. Plastic Strains in SCV for PCV and SCV Head Impact (20\% Celotex Strength)
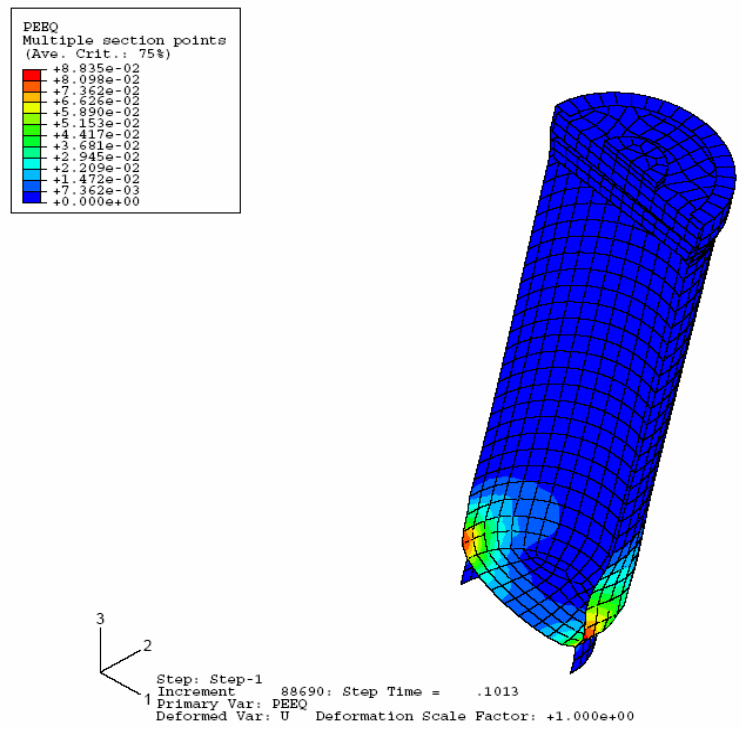

Figure 13. Plastic Strains in PCV for PCV and SCV Head Impact (20\% Celotex Strength) 
Table 1. Series 9975 Package Components

\begin{tabular}{|c|c|c|}
\hline $\begin{array}{c}\text { Item } \\
\text { Number }\end{array}$ & Description & Material \\
\hline 1 & Drum (18.25 I.D. & 304L SST (ASME SA-240) \\
\hline 2 & $\begin{array}{l}\text { Encapsulated } \\
\text { Blanket (12” dia. } \\
\times 1 / 2 ” \text { thk. blanket } \\
\text { core /w } 0.002 \text { “ } \\
\text { thk. jacket) }\end{array}$ & $\begin{array}{l}6 \text { lb/ft }{ }^{3} \text { Kaowool blanket } \\
\text { (Firemaster }{ }^{\circledR} \text { ), } \\
\text { SST jacket }\end{array}$ \\
\hline 3 & $\begin{array}{l}\text { Insulation Top } \\
\text { Subassembly }\end{array}$ & Cane fiberboard (Celotex ${ }^{\circledR}$ ) \\
\hline 4 & $\begin{array}{l}\text { Insulation } \\
\text { Bottom } \\
\text { Subassembly } \\
\end{array}$ & Cane fiberboard (Celotex ${ }^{\circledR}$ ) \\
\hline 5 & $\begin{array}{l}\text { 5.87’/5.563” } \\
\text { O.D. Primary } \\
\text { Containment }\end{array}$ & $\begin{array}{l}\text { 304L SST (ASME SA-312, 403, } \\
\text { 479) }\end{array}$ \\
\hline 6 & $\begin{array}{l}\text { PCV Bottom } \\
\text { Spacer Tube }\end{array}$ & $\begin{array}{l}\text { Aluminum (crush strength=1,500 } \\
\text { psi.) }\end{array}$ \\
\hline 7 & $\begin{array}{l}\text { 7.12"/6.625” } \\
\text { O.D. Secondary } \\
\text { Containment } \\
\end{array}$ & $\begin{array}{l}\text { 304L SST (ASME SA-312, 403, } \\
\text { 479) }\end{array}$ \\
\hline 8 & $\begin{array}{l}\text { SCV Bottom } \\
\text { Spacer Tube }\end{array}$ & $\begin{array}{l}\text { Aluminum (crush strength=1,500 } \\
\text { psi.) }\end{array}$ \\
\hline 9 & $\begin{array}{l}\text { Top Spacer - } \\
\text { Cone Seal Plug }\end{array}$ & 304L SST (ASME SA-479) \\
\hline 10 & $\begin{array}{l}\text { Shielding Body } \\
\text { Subassembly } \\
\text { (8.5”O.D. × } \\
\text { 7.25”I.D.) }\end{array}$ & $\begin{array}{l}\text { Cast lead cylinder (ASTM B- } \\
\text { 749), } 304 \text { SST } \\
\text { tube liner ( } 7.5 ” \text { O.D. } \times 0.06 ” \\
\text { thk.) }\end{array}$ \\
\hline 11 & $\begin{array}{l}\text { 8.5” Dia. } \\
\text { Shielding Lid }\end{array}$ & Aluminum (ASTM B-209) \\
\hline 12 & $\begin{array}{l}(4) 3 / 4 \text { ” Dia. hex } \\
\text { head bolts }\end{array}$ & SST (ASME SA-320, Gr. BB) \\
\hline 13 & 3013 Outer Can & $\begin{array}{l}\text { 316L SST (ASME SA-312, } \\
\text { Body; SA-240, Base) }\end{array}$ \\
\hline
\end{tabular}

